\title{
Recovery of acidified mountain lakes in Norway as predicted by the MAGIC model
}

\author{
Richard F. WRIGHT* and Bernard J. COSBY ${ }^{1)}$ \\ Norwegian Institute for Water Research, Box 173, N-0411 Oslo, Norway \\ ${ }^{1)}$ Department of Environmental Sciences, University of Virginia, Charlottesville, VA 22904-4123, USA \\ *e-mail corresponding author: richard.wright@niva.no
}

\begin{abstract}
As part of the EU project EMERGE the biogeochemical model MAGIC was used to reconstruct acidification history and predict future recovery for mountain lakes in two regions of Norway. Central Norway (19 lakes) receives low levels of acid deposition, most of the lakes have undergone only minor amounts of acidification, and all are predicted to recover in the future. Central Norway thus represents a reference area for more polluted regions in southern Norway and elsewhere in Europe. Southern Norway (23 lakes), on the other hand, receives higher levels of acid deposition, nearly all the studied lakes were acidified and had lost fish populations, and although some recovery has occurred during the period 1980-2000 and additional recovery is predicted for the next decades, the model simulations indicated that the majority of the lakes will not achieve water quality sufficient to support trout populations. Uncertainties in these predictions include possible future $N$ saturation and the exacerbating effects of climate change. The mountain lakes of southern Norway are among the most sensitive in Europe. For southern Norway additional measures such as stricter controls of emissions of air pollutants will be required to obtain satisfactory water quality in the future.
\end{abstract}

Key words: mountain, Norway, lakes, MAGIC, acidification, recovery

\section{INTRODUCTION}

More than 100 years of acid deposition has caused acidification of lakes in Norway and damage to fish and other aquatic organisms (Overrein et al. 1980). Sulphur deposition in Norway peaked in the 1970s, declined by about $60 \%$ from 1980 to 2000 , and is expected to decline further to about $80 \%$ by 2010 relative to 1980 . Nitrogen deposition peaked in the 1980s, has declined by $20 \%$ by 2000 , and is expected to decline further to about $50 \%$ by 2010 relative to 1980 (Schöpp et al. 2003). The decrease in acid deposition is largely the result of international agreements to reduce the emissions of acidifying pollutants to the atmosphere, conducted under the auspices of the UN-ECE Convention on Long-Range Transboundary Air Pollution (LRTAP) (Bull et al. 2001; UNECE 2002).

Lakes in Norway have begun to recover in response to the declining deposition of strong acids. First indications came in the late 1980s (Skjelkvåle \& Henriksen 1995) and became extensive and widespread in the 1990s (Skjelkvåle \& Wright 1998; Skjelkvåle et al. 1998; Skjelkvåle et al. 2001b). Similar trends in recovery have been reported from lakes elsewhere in Fennoscandia (Skjelkvåle et al. 2001a), Europe (Evans et al. 2001; Skjelkvåle et al. 2003), and North America (Stoddard et al. 1999).

Mountain lakes are inherently more sensitive to acid deposition, and thus are typically more severely impacted than forest lakes and require greater reductions in acid deposition to achieve comparable degree of recovery. This is the case for Norwegian mountain lakes (Skjelkvåle \& Wright 1998) and mountain lakes elsewhere in Europe (Mosello et al. 1995).

Mountain lakes have been the object of Europeanwide research projects over the period 1991-2003 under the auspices of the European Union (EU). These projects encompass studies of acid deposition and lake chemistry and include AL:PE I (Acidification of mountain Lakes: Paleolimnology and Ecology; 1991-93) and AL:PE II (1993-95) (Mosello et al. 1995), MOLAR (Measuring and modelling the dynamic response of remote mountain lake ecosystems to environmental change: A programme of Mountain Lake Research; 1996-99) (Mosello et al. 2002), and EMERGE (European Mountain lake Ecosystems: Regionalisation diaGnostics and socio-Economic evaluation; 2000-03) (Marchetto \& Rogora 2004).

Mountain lakes in two districts of Norway (central and southern Norway) have been part of these projects. In the EMERGE project the experimental design entailed a "flagship" site in each district at which detailed long-term studies have been carried out (initiated by $\mathrm{AL}: \mathrm{PE}$ ), and a group of about 20 additional lakes in each of the districts at which less intensive data were collected. Here we used an acidification model (MAGIC version 7; Cosby et al. 1985a, b, 2001) to reconstruct acidification history and to predict future recovery of lakes in the two lake districts, central Norway and southern Norway. 


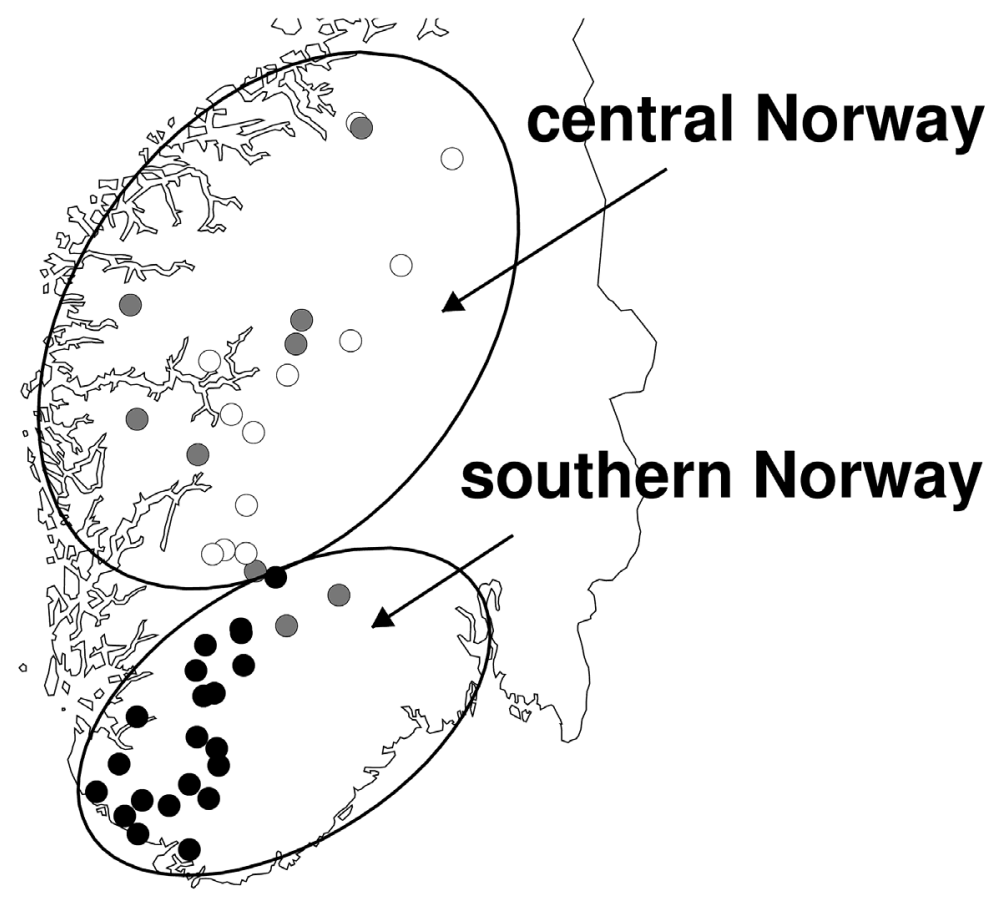

Fig. 1. Map of southern Norway showing locations of the 19 lakes in the dataset central Norway and the 23 lakes in the dataset southern Norway. Symbols indicate the present-day ANC levels in the lakes (light: $>20 \mu$ eq 1 $1^{-1}$; medium: 0-20 $\mu$ eq 1 ${ }^{-1} ;$ dark: $<0 \mu$ eq $1^{-1}$ ).

\section{METHODS}

\subsection{Site descriptions}

The central Norway dataset consists of 22 lakes, of which 19 have complete data necessary for calibration of MAGIC (Appendix 1) (Fig. 1). Lake Øvre Neådalsvatn is the flagship site in this dataset, and has been intensively studied during the AL:PE, MOLAR and EMERGE project periods. The other lakes in the data set were selected subjectively largely from sites for which some data previously existed from earlier studies, and to represent a range in biological habitats. Most of the lakes are situated in areas receiving low levels of acid deposition (year 1995 median non-marine S deposition $12 \mathrm{meq} \mathrm{m}^{-2} \mathrm{y}^{-1}, \mathrm{~N}$ deposition $15 \mathrm{meq} \mathrm{m}^{-2} \mathrm{y}^{-1}$ ), are at most only slightly acidified, and thus serve as a set of unimpacted reference lakes.

The southern Norway dataset consists of 23 lakes located in the four counties of Telemark, Aust-Agder, Vest-Agder and Rogaland (Appendix 2) (Fig. 1). The lakes are part of the Norwegian monitoring programme for long-range transported air pollutants and have been sampled annually for water chemistry since 1986 (15 lakes) or 1995 (8 lakes) (SFT 2002). They are the nonforested sites of the 60 lakes studied as part of the RECOVER project (Wright \& Cosby 2003). Stavsvatn is the flagship site in this dataset. The southern Norway region receives substantial acid deposition (year 2000 median non-marine $\mathrm{S}$ deposition $33 \mathrm{meq} \mathrm{m}^{-2} \mathrm{y}^{-1}, \mathrm{~N}$ deposition 44 meq $\mathrm{m}^{-2} \mathrm{y}^{-1}$ ); most of the lakes are acidified and have damaged fish populations.

\subsection{The MAGIC model}

MAGIC is a process-oriented biogeochemical model for acidification of soils and surface waters originally developed in the 1980s (Cosby et al. 1985a; Cosby et al. 1985b) and recently modified and expanded (version7; Cosby et al. 2001). MAGIC requires as input data information on soil, deposition and surface water chemistry as well as a time sequence of acid deposition from pre-acidification time (usually assumed to be mid1800 s) to a time in the future for which forecasts are to be made (often 2050). The deposition sequences for $\mathrm{S}$ and $\mathrm{N}$ come from estimates prepared by EMEP for southern Norway (Fig. 2) (Schöpp et al. 2003).

\subsection{Calibration}

MAGIC was calibrated in detail to the flagship sites using both the measured water chemistry data for the calibration year (or years) and also the time trends in measured data. The deposition sequences were scaled to each lake based on the assumption that sulphur output was at steady-state with sulphur input for the calibration year. For nitrogen a "best case" assumption was made in which the present-day \% retention of incoming $\mathrm{N}$ was assumed constant over time (i.e. no $\mathrm{N}$ saturation). The calibration followed the procedure given by Wright \& Cosby (2003). The steps are first to calibrate each of the three acid anions $\mathrm{Cl}^{-}, \mathrm{SO}_{4}{ }^{2-}$ and $\mathrm{NO}_{3}{ }^{-}$separately, then the base cations $\mathrm{Ca}^{2+}, \mathrm{Mg}^{2+}, \mathrm{Na}^{+}$, and $\mathrm{K}^{+}$together, and finally the weak acids and base ions $\mathrm{Al}^{\mathrm{n+}}$ (sum of positivelycharged aluminium species), $\mathrm{A}^{-}$(organic anions) and $\mathrm{HCO}_{3}{ }^{-}$. The values for acid neutralising capacity (ANC) 


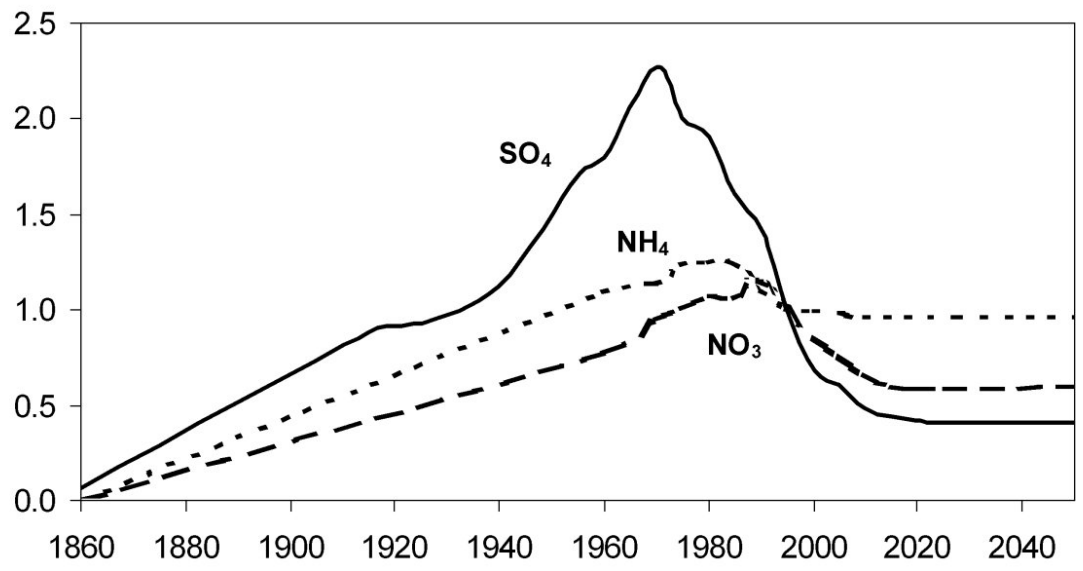

Fig. 2. Historical and future deposition of non-marine $\mathrm{SO}_{4}{ }^{2-}, \mathrm{NO}_{3}{ }^{-}$and $\mathrm{NH}_{4}{ }^{+}$used in MAGIC applications for Norway. The curves were scaled to the calibration period (central Norway 2000; southern Norway 1995-97) (data from Schöpp et al. 2003).

and $\mathrm{H}^{+}$provide a measure of the closeness of the calibration. ANC is defined in the usual manner as the equivalent sum of base cations minus the equivalent sum of strong acid anions. Input data are given in Appendix 1 and 2 . An automatic calibration routine was used to calibrate the two regional datasets.

\subsection{Link between water chemistry and biological response}

Surveys of lakewater chemistry and fish population status in Norwegian lakes show a clear empirical relationship between ANC and fish status. For brown trout, the most common fish species in Norwegian mountain lakes, lakes with $\mathrm{ANC}>20 \mu \mathrm{eq} \mathrm{l}^{-1}$ have $95 \%$ probability of good population, lakes with ANC 0-20 $\mu \mathrm{eq} \mathrm{l}^{-1}$ have sparse population, while lakes with $\mathrm{ANC}<0 \mu \mathrm{eq}$ $1^{-1}$ have $95 \%$ probability of extinct population (Lien et al. 1996). Similar empirical relationships exist between other fish species as well as acid-sensitive invertebrate species.

Toxicity of acid water to brown trout is primarily due to increased concentrations of $\mathrm{Al}^{\mathrm{n}+}$, with $\mathrm{pH}$ and concentration of $\mathrm{Ca}^{2+}$ secondary factors (Baker \& Schofield 1980; Muniz \& Leivestad 1980). Statistical analysis shows that ANC, however, explains nearly as much of the variance, because of the high correlation between $\mathrm{ANC}$ and $\mathrm{pH}, \mathrm{Al}^{\mathrm{n}+}$ and $\mathrm{Ca}^{2+}$ (Bulger et al. 1993; Cosby et al. 1994). As biogeochemical models such as MAGIC predict ANC much better than $\mathrm{pH}$ or $\mathrm{Al}^{\mathrm{n}+}$, we use ANC levels to interpret water chemistry changes to biological effects.

\section{RESULTS}

\subsection{Central Norway}

The calibration for Øvre Neådalsvatn showed very little change in lakewater ANC over the entire 200-year simulation (Fig. 3). The values for 1991-2000 agreed well with the observations (yearly mean values). Seventeen of the 19 lakes in the dataset had simulated ANC trends similar to that of Øvre Neådalsvatn, with only minor changes over time. The remaining two lakes showed larger changes in ANC; this was due to the somewhat higher $\mathrm{S}$ deposition and very thin soil cover at these sites as compared to the bulk of the dataset. For the dataset as a whole the median change in ANC due to acid deposition was only about $10 \mu \mathrm{eq} \mathrm{l}^{-1}$. Less than $50 \%$ of the lakes acidified to below the threshold of ANC $20 \mu$ eq $1^{-1}$ where damage to brown trout might be expected. The simulations indicated that these lakes have recovered substantially since the peak year of acid deposition in the 1970s and will continue to recover slightly during the next decade. Less than $25 \%$ of the lakes will have ANC $<20 \mu \mathrm{eq} \mathrm{l}^{-1}$ in the future (Fig. 4).

The MAGIC simulations also provided an indication of changes in soil base cation pools ( $\%$ base saturation) due to acid deposition. Again with the exception of two lakes, there were only very small changes in $\% \mathrm{BS}$ over the 200-year period. The simulations showed, however, clear asymmetry; the pool sizes decreased in many lakes during the past 100 years, whereas the replenishment predicted starting in the 1970s is much smaller (Fig. 3; lower left-hand panel). The MAGIC simulations indicate that while soils were acidifying in 1980, the decline in acid deposition since then has stopped further acidification and base cation pools in soils in some catchments will be replenished in the future (Fig. 4).

\subsection{Southern Norway}

The calibration for Stavsvatn showed significant decline in ANC during the period up to about 1980, partial recovery to the year 2000, and prognosis of a minor amount of additional recovery during the next 20 years (Fig. 3). Stavsvatn is the least acidified lake of the 23 in the dataset; the other lakes all acidified to ANC $<0 \mu$ eq $1^{-1}$ during the 1900s. With the exception of Stavsvatn, 
Central Norway

Øvre Neådalsvatn ANC

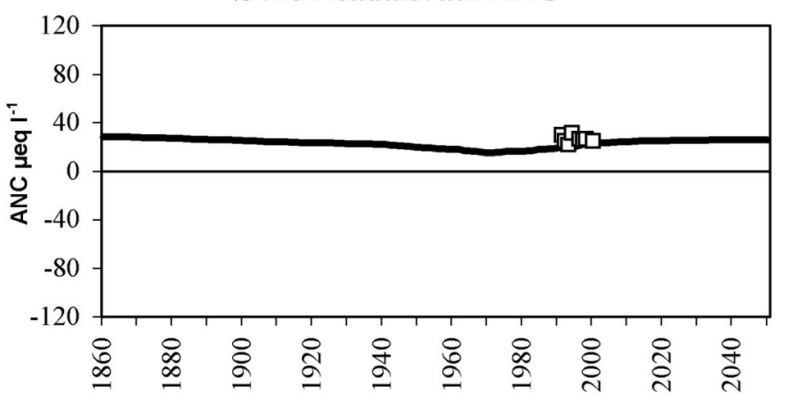

lake ANC

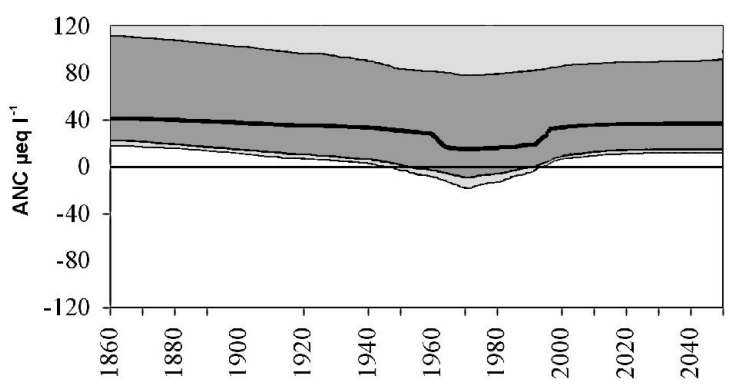

soil: change in base cation pool

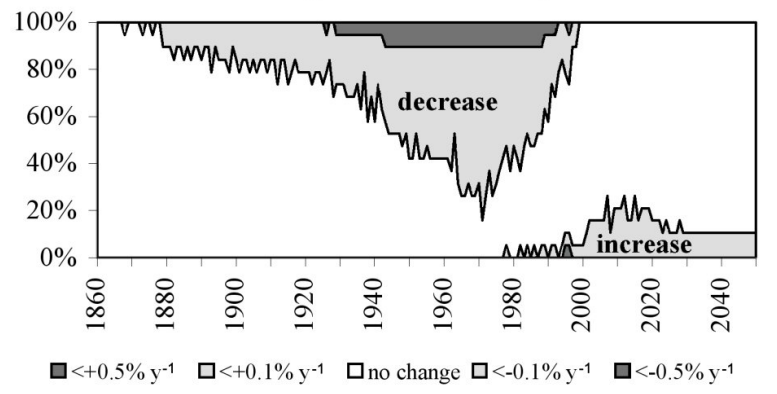

Southern Norway

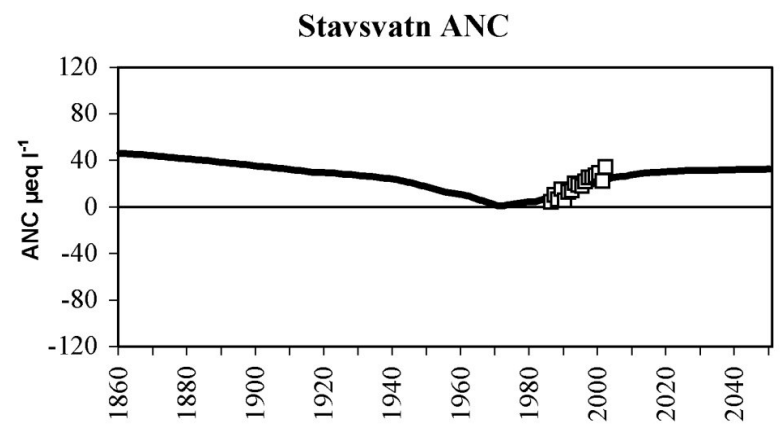

lake ANC

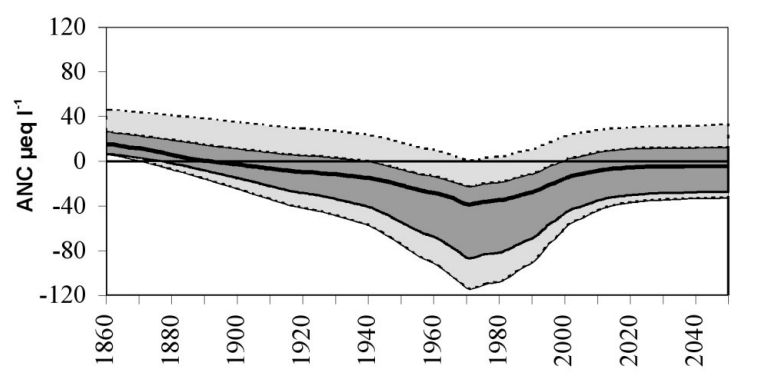

soil: change in base cation pool

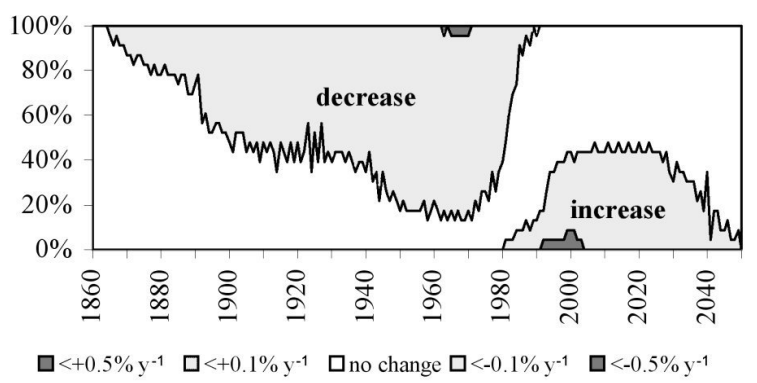

Fig. 3. ANC in lakewater and changes in base cation pools in soils in the lake districts central Norway (left-hand panels) and southern Norway (right-hand panels) as simulated by MAGIC. Upper panels: ANC in lakewater at the flagship site as simulated by MAGIC and the 1986-2000 yearly measured values. Middle panels: the frequency distribution of the lake datasets (heavy black line: median; dark shading: 10-90 \%-tile; light shading: minimum-maximum). Lower panels: percent of lakes with annual change in base cation pool (shaded area: decrease or increase in pool; white: no change).

which is stocked every second year by the owners, most of the lakes were barren of trout in the 1980s. ANC levels have recovered substantially since then, and the MAGIC simulations predict that additional recovery will come during the next 20 years. Only Stavsvatn, however, is predicted to recover to $\mathrm{ANC}>20 \mu \mathrm{eq} \mathrm{l}^{-1}$, and about $60 \%$ of the lakes are predicted to remain

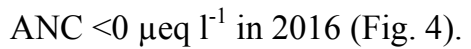

The MAGIC simulations indicated that the soils at these sites have acidified during the past 100 years, and that the base cation pools will not be fully replenished in the next 50 years. As in central Norway the simulations showed a marked asymmetry with more acidification and less recovery. The simulations indicate that impov- erishment of pool of base cations in soil has largely ceased by 2000 and that in about one-half of the catchments the pools will begin to be replenished in the future (Fig. 4).

\section{DISCUSSION}

The lakes in the region central Norway were intended to serve as unacidified reference sites for the more acidified and impacted lakes in the southern Norway region. The MAGIC hindcasts, however, indicate that many of the lakes in the central Norway region have been slightly acidified and that 5 of the lakes had ANC levels $<0 \mu$ eq $1^{-1}$ during the period of maximum acid deposition in the 1970s and 1980s (Figs 3 and 4). 


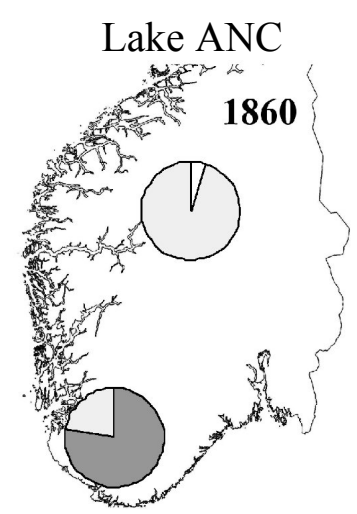

Soil: change in base cation pool
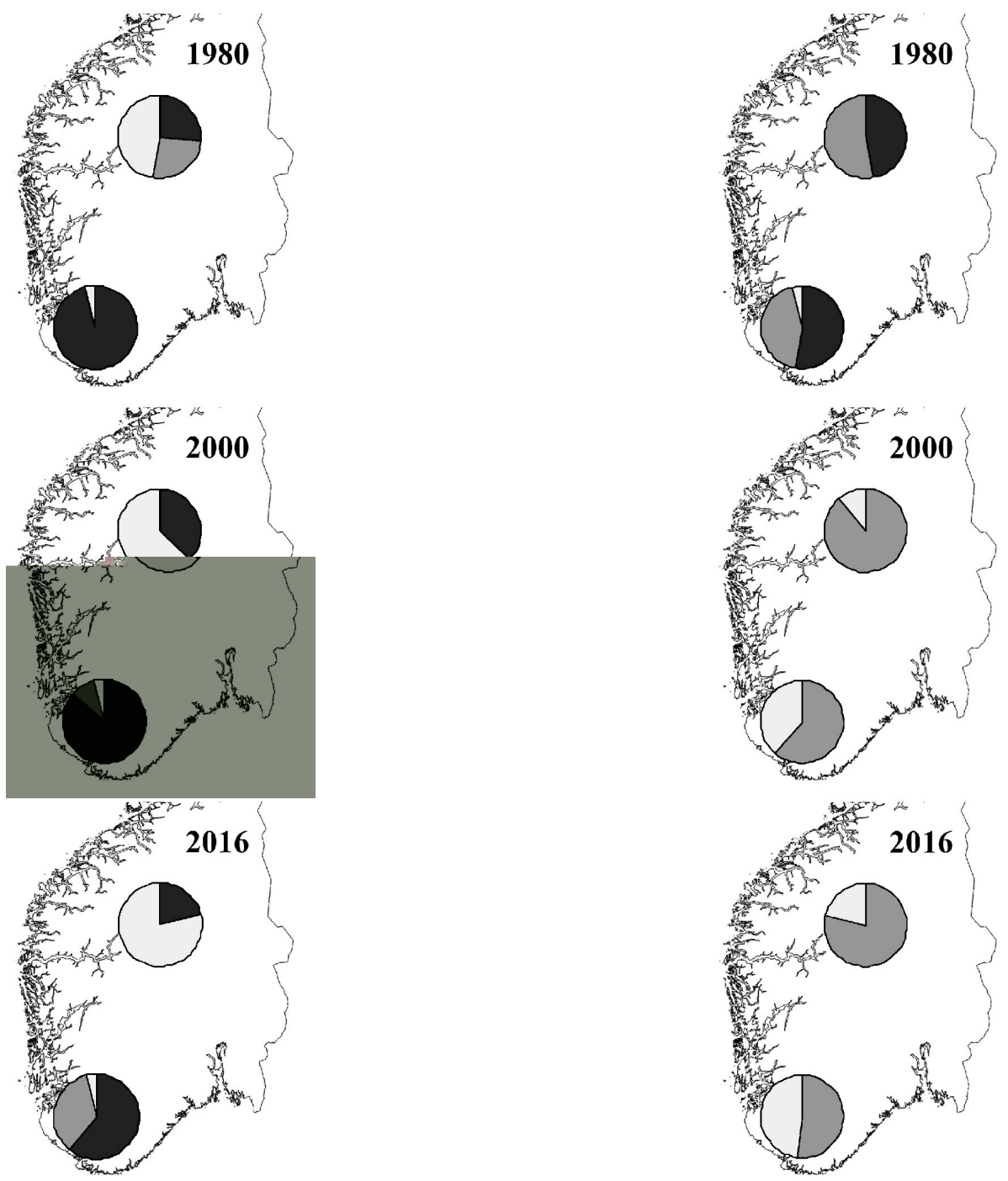

Fig. 4. ANC levels in lakes and annual changes in soil base cation pools in central and southern Norway for key years as predicted by MAGIC. Left-hand panels: \% of lakes in each of three ANC categories corresponding to fish population status. Light shading: ANC

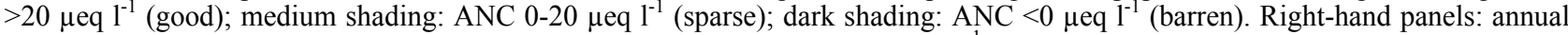
incremental change in pools of base cations. Dark shading: pool change $<0.1 \% \mathrm{y}^{-1}$; medium shading: no change; light shading: pool change $>0.1 \% \mathrm{y}^{-1}$. 
Acidification in central Norway, however, has been much less than that in southern Norway. The difference in degree of acidification between central Norway and southern Norway is due largely to the relatively larger input of acid deposition to the southern region. In addition several of the central Norway lakes are less sensitive to acid deposition; these lakes have higher concentrations of $\mathrm{Ca}$ and bicarbonate.

The model predictions indicate that recovery of the lakes to ANC levels $>20 \mu \mathrm{eq}^{-1}$ will not occur by the year 2016. For central Norway a larger fraction of the lakes will still fall in the category ANC 0-20 $\mu \mathrm{eq} \mathrm{l}^{-1}$ in 2016 as compared to the pre-acidification reference year 1860 (Fig. 4). For southern Norway recovery by year 2016 will be insufficient; fully $2 / 3$ of the lakes will continue to have ANC $<0 \mu \mathrm{eq} \mathrm{l}^{-1}$. This is in part because although levels of acid deposition are predicted to continue to decrease to the year 2010 if the Gothenburg protocol to the LRTAP Convention is implemented (Fig. 2), there will still remain a small but significant $\mathrm{S}$ and $\mathrm{N}$ deposition in the future.

Part of the incomplete recovery is due to the hysteresis in the size of the pool of base cations in the soil over time. This pool is depleted by cation exchange with acids deposited from the atmosphere and leaching to runoff, and replenished by weathering of soil minerals. The MAGIC simulations indicate that depletion exceeded replenishment during much of the 1900s, but by year 2000 acid deposition had decreased sufficiently to allow replenishment to begin (Fig. 3; lower panels). The simulations indicate that the replenishment of the soil base cation pool will require many decades.

The 23 mountain lakes in the southern Norway dataset are a subset of the 60 lakes in the region modelled by Wright \& Cosby (2003) as part of the RECOVER:2010 project. The mountain lakes are in general more sensitive to acid deposition, and leach a higher \% of incoming $\mathrm{N}$ as compared to the lowland, forest lakes. These features are typical for mountain lakes in general (Skjelkvåle \& Wright 1998).

All predictions for the future entail a degree of uncertainty, and these predictions for the future acidification of Norwegian mountain lakes are no exceptions. Uncertainties are associated with measured input data, estimated parameters, model formulation and structure, and with factors not considered in the model. The assumption of constant $\%$ retention of $\mathrm{N}$ is a source of uncertainty. The magnitude of this uncertainty was evaluated by Wright \& Cosby (2003) for the MAGIC predictions for the 60 lakes in southern Norway of the RECOVER dataset. Three different scenarios for $\mathrm{N}$ retention were run; these were constant $\% \mathrm{~N}$ retention, $\%$ $\mathrm{N}$ retention linked to $\mathrm{C} / \mathrm{N}$ ratio of the organic matter in soil with carbon pool of the whole soil, and \% retention linked to $\mathrm{C} / \mathrm{N}$ ratio with carbon pool only $1 / 3$ of the total. Although nitrate concentrations predicted by MAGIC for the year 2036 differed by a factor of two among these scenarios, the median resulting effect on ANC levels differed by only $5 \mu$ eq $1^{-1}$. Thus the uncertainty to predictions of ANC over the next 20-30 years caused by unknown degree of future $\mathrm{N}$ saturation is minor.

Future climate change with increased temperature represents another uncertainty factor for future recovery of lakes. Higher soil temperature can cause increased decomposition of soil organic matter and release $\mathrm{NO}_{3}$ to soil solution and runoff thus increasing acidification. Whole-ecosystem experiments with air and soil warming conducted in southernmost Norway (the CLIMEX project) showed increase in $\mathrm{NO}_{3}$ concentrations in runoff of about 3-7 $\mu$ eq $1^{-1}$ (Lükewille \& Wright 1997; Wright 1998). These experiments lasted only three years, however, and thus do not give information as to whether the induced $\mathrm{NO}_{3}$ leaching would increase, stay elevated, or disappear over the long term.

The MAGIC prognoses here already indicate that a substantial fraction of mountain lakes in southern Norway will not recover sufficiently by year 2016 (or indeed by year 2036) to allow reestablishment of good brown trout populations. Both $\mathrm{N}$ saturation and future climate change are factors that would exacerbate acidification in southern Norway in the future. Sufficient recovery requires additional measures such as stricter air pollutant emission measures in Europe. Mountain lakes in southern Norway are among the most acid-sensitive lakes in Europe, and MAGIC simulations conducted as part of the RECOVER and EMERGE projects indicate that of all the studied regions in Europe, the acidification situation for mountain lakes will be worst in southern Norway in the future (Jenkins et al. 2003).

\section{ACKNOWLEDGMENTS}

This work was carried out as part of the EMERGE project (the Commission of European Communities EVK1-CT-1999-00032). The work was financially supported in part by the Nordic Council of Ministers, the Research Council of Norway, and the Norwegian Institute for Water Research. We thank Tore Høgaasen at NIVA for expert assistance including multiple trials of the multiple calibrations. We thank Gunnar Raddum, Arne Fjellheim and Øyvind Schnell for water samples from central Norway.

\section{REFERENCES}

Baker, J.P. \& C.L. Schofield. 1980. Aluminium toxicity to fish as related to acid precipitation and Adirondack surface water quality. In: Drabløs, D. \& A. Tollan (Eds), Ecological Impact of Acid Precipitation. SNSF-project. Ås, Norway: 292-293.

Bulger, A.J., L. Lien, B.J. Cosby \& A. Henriksen. 1993. Brown trout (Salmo trutta) status and chemistry from the Norwegian thousand lake survey: statistical analysis. Can. J. Fish. Aquat. Sci., 50: 575-585.

Bull, K.R., B. Achermann, V. Bashkin, R. Chrast, G. Fenech, M. Forsius, H-D. Gregor, R. Guardans, T. Haussmann, F. Hayes, J.-P. Hettelingh, T. Johannessen, M. 
Krzyzanowski, V. Kucera, B. Kvæven, M. Lorenz, L. Lundin, G. Mills, M. Posch, B.L. Skjelkvåle \& M.J. U1stein. 2001. Coordinated effects monitoring and modelling for developing and supporting international air pollution control agreements. Water Air Soil Pollut., 130: 119-130.

Cosby, B.J., A.J. Bulger \& R.F. Wright. 1994. Predicting recovery of freshwater ecosystems: trout in Norwegian lakes. In: Steinberg, C.E.W. \& R.F. Wright (Eds). Acidification of Freshwater Ecosystems. Implications for the Future. Wiley \& Sons, Chichester, UK: 355-374.

Cosby, B.J., R.C. Ferrier, A. Jenkins \& R.F. Wright. 2001a. Modelling the effects of acid deposition: refinements, adjustments and inclusion of nitrogen dynamics in the MAGIC model. Hydrol. Earth System Sci., 5: 499-518.

Cosby, B.J., G.M. Hornberger, J.N. Galloway \& R.F. Wright. 1985b. Modelling the effects of acid deposition: assessment of a lumped parameter model of soil water and streamwater chemistry. Water Res. Research, 21: 51-63.

Cosby, B.J., R.F. Wright, G.M. Hornberger \& J.N. Galloway, 1985. Modelling the effects of acid deposition: estimation of long term water quality responses in a small forested catchment. Water Res. Research, 21: 1591-1601.

Evans, C.D., J. Cullen, C. Alewell, J. Kopácek, A. Marchetto, F. Moldan, A. Prechtel, M. Rogora, J. Veselý \& R.F. Wright. 2001. Recovery from acidification in European surface waters. Hydrol. Earth System Sci., 5: 283-298.

Jenkins, A., L. Camarero, B.J. Cosby, R.C, Ferrier, M. Forsius, R.C. Helliwell, J. Kopácek, V. Majer, F. Moldan, M. Posch, M. Rogora, W. Schöpp, \& R.F. Wright. 2003. A modelling assessment of acidification and recovery of European surface waters. Hydrol. Earth System Sci., 7: 447-455.

Lükewille, A. \& R.F. Wright. 1997. Experimentally increased soil temperature causes release of nitrogen at a boreal forest catchment in southern Norway. Global Change Biology, 3: 13-21.

Lien, L., G.G. Raddum, A. Fjellheim \& A. Henriksen. 1996. A critical limit for acid neutralizing capacity in Norwegian surface waters, based on new analyses of fish and invertebrate responses. Sci. Tot. Environ., 177: 173-193.

Marchetto, A. \& M. Rogora. 2004. Measured and modelled trends in European mountain lakes: results of fifteen years of cooperative studies. J.Limnol. 63 (1): 55-62.

Mosello, R., A. Lami, A. Marchetto, M. Rogora, B.M. Wathne, L. Lien, J. Catalan, L. Camarero, M. Ventura, R. Psenner, K. Koining, H. Thies, S. Sommaruga-Wögrath, U. Nickus, D. Tait, R. Thaler, A. Barbieri, \& R. Harriman. 2002. Trends in the water chemistry of high altitude lakes in Europe. Water Air and Soil Pollution: Focus, 2 : 75-89.

Mosello, R., B.M. Wathne, L. Lien, \& H.J.B. Birks. 1995. AL:PE projects: water chemistry and critical loads. Water Air Soil Pollut., 85: 493-498.
Muniz, I.P. \& H. Leivestad. 1980. Toxic effects of aluminium on the brown trout (Salmo trutta L.). In: Drabløs, D. \& A. Tollan (Eds), Ecological Impact of Acid Precipitation. SNSF-project. Ås, Norway: 320-321.

Overrein, L., H.M. Seip \& A. Tollan. 1980. Acid precipitation - Effects on forest and fish. Final report of the SNSF-project 1972-1980. Fagrapport FR 19-80, Oslo-Ås, Norway: $175 \mathrm{pp}$.

Schöpp, W., M. Posch, S. Mylona \& M. Johansson. 2003. Long-term development of acid deposition (1880-2030) in sensitive freshwater regions in Europe. Hydrol. Earth System Sci., 7: 436-446.

SFT. 2002. Overvåking av langtransportert forurenset luft og nedbør. Arsrapport - Effekter 2001. Statlig program for forurensningsovervåking Rapport 854/02, Statens forurensningstilsyn, Oslo, Norge: $194 \mathrm{pp}$.

Skjelkvåle, B.L., C.D. Evans, T. Larssen, A. Hindar \& G.G. Raddum. 2003. Recovery from acidification in European surface waters: A view to the future. Ambio, 30: 170-175.

Skjelkvåle, B.L. \& A. Henriksen. 1995. Acidification in Norway -- status and trends. Surface and ground water. Water Air Soil Pollut., 85: 629-634.

Skjelkvåle, B.L., J. Mannio, A. Wilander \& T. Andersen. 2001a. Recovery from acidification of lakes in Finland, Norway and Sweden 1990-1999. Hydrol. Earth System Sci., 5: 327-338.

Skjelkvåle, B.L., K. Tørseth, W. Aas, \& T. Andersen. 2001 b. Decrease in acid deposition - Recovery in Norwegian surface waters. Water Air Soil Pollut., 130: 1433-1438.

Skjelkvåle, B. L. \& R. F. Wright. 1998. Mountain lakes: sensitivity to acid deposition and global climate change. Ambio, 27: 280-286.

Skjelkvåle, B.L., R.F. Wright \& A. Henriksen. 1998. Norwegian lakes show widespread recovery from acidification: results of national surveys of lakewater chemistry 19861997. Hydrol. Earth System Sci., 2: 555-562.

Stoddard, J.L., D.S. Jeffries, A. Lükewille, T.A. Clair, P.J. Dillon, C.T. Driscoll, M. Forsius, M. Johannessen, J.S. Kahl, J.H. Kellogg, A. Kemp, J. Mannio, D. Monteith, P.S. Murdoch, S. Patrick, A. Rebsdorf, B.L. Skjelkvåle, M.P. Stainton, T.S. Traaen, H. van Dam, K.E. Webster, J. Wieting \& A. Wilander. 1999. Regional trends in aquatic recovery from acidification in North America and Europe 1980-95. Nature, 401: 575-578.

UNECE. 2002. http://www.unece.org/env/lrtap/.

Wright, R.F. 1998. Effect of increased CO2 and temperature on runoff chemistry at a forested catchment in southern Norway (CLIMEX project). Ecosystems, 1: 216-225.

Wright, R.F. \& B.J. Cosby. 2003. Future recovery of acidified lakes in southern Norway predicted by the MAGIC model. Hydrol. Earth System Sci., 7: 467-483. 


\section{APPENDIX 1}

Central Norway dataset. Site, lake chemistry and soil data. Catchment area includes the lake area. $\mathrm{P}=$ precipitation. $\mathrm{Q}=$ runoff.

\begin{tabular}{|c|c|c|c|c|c|c|c|c|c|}
\hline ID & Name & Latitude & Longitude & $\begin{array}{l}\text { elevation } \\
\text { (m a.s.1.) }\end{array}$ & $\begin{array}{l}\text { catchment } \\
\left(\mathrm{km}^{2}\right)\end{array}$ & $\begin{array}{c}\text { lake } \\
\left(\mathrm{km}^{2}\right)\end{array}$ & Bedrock & $\begin{array}{c}\mathrm{P} \\
\left(\mathrm{m} \mathrm{yr}^{-1}\right)\end{array}$ & $\begin{array}{c}\mathrm{Q} \\
\left(\mathrm{m} \mathrm{yr}^{-1}\right)\end{array}$ \\
\hline CN0001 & Vonavatn & 61.6131 & 6.0054 & 466 & 88.8 & 1.65 & granite & 2.52 & 2.37 \\
\hline CN0002 & Vestre Kvammavatn & 60.9004 & 6.1556 & 990 & 1.9 & 0.3 & phylite & 1.14 & 0.99 \\
\hline CN0003 & Slondalsvatn & 60.6921 & 6.9489 & 751 & 41.5 & 0.6 & gabbro & 2.29 & 2.14 \\
\hline CN0004 & Halsavatnet & 61.2793 & 7.0656 & 820 & 1.5 & 0.27 & phylite & 1.32 & 1.17 \\
\hline CN0005 & Litlosvatn & 60.0738 & 7.1708 & 1172 & 61.2 & 1.53 & phylite & 1.52 & 1.37 \\
\hline CN0006 & Valgardsvatn & 60.1028 & 7.3184 & 1324 & 11.8 & 1.8 & phylite & 1.39 & 1.24 \\
\hline $\mathrm{CN} 0007$ & Hornsvatnet & 60.9501 & 7.3625 & 1289 & 2.1 & 0.3 & gneiss & 1.58 & 1.43 \\
\hline CN0008 & Dargesjåen & 60.0844 & 7.5890 & 1209 & 17.3 & 0.55 & gneiss & 1.14 & 0.99 \\
\hline CN0009 & Skiftesjøen & 60.3842 & 7.5797 & 1239 & 5.6 & 0.95 & phylite & 1.69 & 1.54 \\
\hline CN0010 & Holmavatnet & 60.8420 & 7.6514 & 1525 & 8.1 & 0.8 & gabbro & 1.76 & 1.62 \\
\hline CN0011 & Urdevatn & 59.9734 & 7.7120 & 1329 & 24.5 & 1.5 & granite & 1.38 & 1.23 \\
\hline CN0012 & Grønevatnet & 61.2011 & 8.0790 & 1184 & 16.3 & 1.3 & $\begin{array}{c}\text { granite- } \\
\text { amphibolite }\end{array}$ & 1.36 & 1.21 \\
\hline CN0013 & Kvitevatnet & 61.3957 & 8.1781 & 1396 & 8.5 & 1.4 & gabbro & 2.04 & 1.89 \\
\hline CN0014 & Leirvatnet & 61.5478 & 8.2493 & 1401 & 12.5 & 1.0 & gneiss & 1.38 & 1.23 \\
\hline CN0015 & Øvre Heimdalsvatnet & 61.4188 & 8.8970 & 1088 & 24.4 & 0.78 & gabbro & 0.94 & 0.79 \\
\hline CN0016 & Øvre Neådalsvatn & 62.7778 & 8.9824 & 728 & 16.0 & 0.5 & gneiss & 1.95 & 1.80 \\
\hline CN0017 & Fallbekktjørna & 62.7500 & 9.0372 & 1043 & 3.7 & 0.27 & gneiss & 1.95 & 1.80 \\
\hline CN0018 & Høvringvatn & 61.8898 & 9.5650 & 1121 & 2.5 & 0.18 & quartzite & 0.62 & 0.47 \\
\hline CN0019 & Lille Innsjøen & 62.5522 & 10.2659 & 938 & 5.1 & 0.4 & schist & 0.58 & 0.43 \\
\hline CN0020 & Haltdalstjønna & 62.7743 & 11.0670 & 1058 & 1.9 & 0.08 & gabbro & 0.72 & 0.57 \\
\hline CN0021 & Gjeltsjøen & 62.7160 & 11.6009 & 799 & 19.9 & 0.55 & phylite & 0.72 & 0.57 \\
\hline CN0022 & Øvlingen & 62.9029 & 11.7848 & 844 & 1.2 & 0.2 & gabbro & 0.72 & 0.57 \\
\hline
\end{tabular}

Lake chemistry. Alk= alkalinity titrated to fixed $\mathrm{pH} 4.5$ less $32 \mu \mathrm{eq} \mathrm{l}^{-1}$.

\begin{tabular}{|c|c|c|c|c|c|c|c|c|c|c|c|c|c|c|c|c|c|}
\hline ID & Year & $\begin{array}{c}\text { Date } \\
(\mathrm{ddmm})\end{array}$ & $\mathrm{pH}$ & $\begin{array}{c}\mathrm{Ca} \\
\left(\mu \mathrm{eq} \mathrm{l}^{-1}\right)\end{array}$ & $\begin{array}{c}\mathrm{Mg} \\
\left(\mu \mathrm{eq} \mathrm{l}^{-1}\right)\end{array}$ & $\begin{array}{c}\mathrm{Na} \\
\left(\mu \text { eq } 1^{-1}\right)\end{array}$ & $\left.{ }^{1}\right)\left(\mu \mathrm{eq} \mathrm{l}^{-1}\right)$ & $\begin{array}{c}\mathrm{Cl} \\
\left(\mu \mathrm{eq} \mathrm{l}^{-1}\right)\end{array}$ & $\begin{array}{c}\mathrm{SO}_{4} \\
\left(\mu \mathrm{eq} \mathrm{l}^{-1}\right)\end{array}$ & $\begin{array}{c}\mathrm{NO}_{3} \\
\left(\mu \mathrm{eq} \mathrm{l}^{-1}\right)\end{array}$ & $\begin{array}{c}\text { Alk } \\
\left(\mu \text { eq } 1^{-1}\right)\end{array}$ & $\begin{array}{c}\text { TOC } \\
\left(\mathrm{mg} \mathrm{l}^{-1}\right)\end{array}$ & $\begin{array}{c}\mathrm{R}-\mathrm{Al} \\
\left(\mu \mathrm{g} \mathrm{l}^{-1}\right)\end{array}$ & $\begin{array}{l}\text { org-Al } \\
\left(\mu \mathrm{g} \mathrm{l}^{-1}\right)\end{array}$ & $\begin{array}{c}\text { in-Al } \\
\left(\mu \mathrm{g}^{-1}\right)\end{array}$ & $\begin{array}{c}\text { tot-P } \\
\left(\mu \mathrm{g} \mathrm{I}^{-1}\right)\end{array}$ & $\begin{array}{l}\text { tot-N } \\
\left(\mu \mathrm{g}^{-1}\right)\end{array}$ \\
\hline CN0001 & 2000 & 0929 & 5.84 & 15 & 10 & 39 & 3 & 42 & 15 & 2 & 7 & 1.1 & 19 & 14 & 5 & 2 & 96 \\
\hline $\mathrm{CN} 0002$ & 2000 & 1009 & 5.95 & 18 & 7 & 30 & 3 & 31 & 17 & 3 & 7 & 0.0 & 3 & 3 & 0 & 4 & 117 \\
\hline $\mathrm{CN} 0003$ & 2000 & 1007 & 5.94 & 15 & 6 & 17 & 3 & 14 & 15 & 3 & 6 & 0.4 & 3 & 3 & 0 & 3 & 80 \\
\hline $\mathrm{CN} 0004$ & 2000 & 1025 & 6.64 & 72 & 12 & 22 & 6 & 23 & 21 & 2 & 52 & 2.0 & 11 & 11 & 0 & 2 & 117 \\
\hline $\mathrm{CN} 0005$ & 2000 & 1210 & 6.79 & 82 & 17 & 17 & 1 & 14 & 33 & 2 & 55 & 0.2 & 3 & 3 & 0 & 1 & 60 \\
\hline CN0006 & 2000 & 1110 & 6.47 & 115 & 7 & 23 & 2 & 20 & 83 & 3 & 31 & 0.3 & 3 & 3 & 0 & 0 & 72 \\
\hline $\mathrm{CN} 0007$ & 2000 & 0905 & 6.25 & 27 & 8 & 14 & 5 & 8 & 19 & 0 & 20 & 0.7 & 3 & 3 & 0 & 2 & 56 \\
\hline $\mathrm{CN} 0008$ & 2000 & 1110 & 6.43 & 45 & 9 & 23 & 3 & 11 & 23 & 0 & 27 & 0.8 & 6 & 5 & 1 & 0 & 83 \\
\hline CN0009 & 2000 & 0922 & 6.75 & 101 & 13 & 21 & 2 & 14 & 50 & 0 & 56 & 0.6 & 3 & 3 & 0 & 3 & 90 \\
\hline CN0010 & 2001 & 1016 & 6.48 & 51 & 23 & 35 & 6 & 19 & 24 & 0 & 47 & 4.6 & 29 & 31 & 0 & 4 & 155 \\
\hline CN0011 & 2000 & 1110 & 6.07 & 24 & 6 & 16 & 2 & 11 & 19 & 1 & 9 & 0.8 & 6 & 5 & 1 & 0 & 57 \\
\hline CN0012 & 2000 & 0913 & 6.45 & 33 & 9 & 17 & 4 & 14 & 15 & 1 & 27 & 0.3 & 3 & 3 & 0 & 2 & 75 \\
\hline CN0013 & 1995 & 0918 & 5.99 & 23 & 5 & 9 & 1 & 6 & 21 & 4 & 15 & 0.1 & 5 & 5 & 0 & 1 & 81 \\
\hline CN0014 & 2000 & 0916 & 6.29 & 25 & 6 & 9 & 2 & 3 & 17 & 2 & 23 & 0.2 & 3 & 3 & 0 & 1 & 71 \\
\hline CN0015 & 2000 & 0915 & 6.93 & 80 & 30 & 26 & 6 & 3 & 31 & 0 & 88 & 0.8 & 6 & 3 & 4 & 2 & 75 \\
\hline CN0016 & 2000 & 0818 & 6.22 & 17 & 7 & 30 & 3 & 23 & 10 & 0 & 17 & 0.7 & 12 & 10 & 2 & 1 & 62 \\
\hline CN0017 & 2000 & 0818 & 6.09 & 18 & 8 & 30 & 3 & 25 & 12 & 1 & 13 & 0.2 & 8 & 5 & 3 & 1 & 41 \\
\hline CN0018 & 1995 & 1015 & 6.79 & 67 & 23 & 20 & 6 & 6 & 27 & 1 & 55 & 1.2 & 5 & 5 & 0 & 0 & 62 \\
\hline CN0019 & 2001 & 1003 & 7.65 & 445 & 31 & 32 & 23 & 17 & 31 & 0 & 467 & 2.1 & 16 & 3 & 14 & 2 & 137 \\
\hline CN0020 & 2000 & 1024 & 6.14 & 16 & 6 & 8 & 4 & 6 & 15 & 1 & 10 & 0.3 & 3 & 3 & 0 & 2 & 74 \\
\hline CN0021 & 1995 & 0920 & 7.20 & 207 & 43 & 21 & 10 & 20 & 15 & 1 & 232 & 2.8 & 5 & 5 & 0 & 4 & 210 \\
\hline $\mathrm{CN} 0022$ & 2001 & 0824 & 7.65 & 347 & 119 & 50 & 27 & 42 & 56 & 0 & 413 & 1.6 & 16 & 3 & 14 & 3 & 105 \\
\hline
\end{tabular}


Soil chemistry. Depth=estimated average for catchment. $\mathrm{CEC}=$ cation exchange capacity by $1 \mathrm{M} \mathrm{NH}_{4} \mathrm{NO}_{3}$. BD=bulk density. Exchangeable base cations in \% of CEC. N/A= not available.

\begin{tabular}{|c|c|c|c|c|c|c|c|c|c|c|c|}
\hline ID & soil data source & $\begin{array}{l}\text { Depth } \\
(\mathrm{m})\end{array}$ & $\begin{array}{c}\text { CEC } \\
\left(\text { meq kg }^{-1}\right)\end{array}$ & $\begin{array}{c}\mathrm{BD} \\
\left(\mathrm{kg} \mathrm{m}^{-3}\right)\end{array}$ & $\begin{array}{c}\mathrm{Ca} \\
(\%)\end{array}$ & $\begin{array}{l}\mathrm{Mg} \\
(\%)\end{array}$ & $\begin{array}{l}\mathrm{Na} \\
(\%)\end{array}$ & $\begin{array}{c}\mathrm{K} \\
(\%)\end{array}$ & $\begin{array}{c}\mathrm{C} \\
\left.(\mathrm{mol} \mathrm{m})^{-2}\right)\end{array}$ & $\begin{array}{c}\mathrm{N} \\
\left(\mathrm{mol} \mathrm{m}^{-2}\right)\end{array}$ & $\begin{array}{c}\mathrm{C} / \mathrm{N} \\
\left(\mathrm{mol} \mathrm{mol}^{-1}\right)\end{array}$ \\
\hline CN0001 & Naustdal & 0.75 & 62 & 800 & 7.9 & 3.6 & 4.4 & 2.4 & N/A & N/A & N/A \\
\hline CN0002 & Vosso 1 & 0.30 & 98 & 542 & 7.5 & 5.5 & 1.3 & 4.1 & 1340 & 36 & 37 \\
\hline CN0003 & Vosso4 & 0.20 & 52 & 1099 & 0.7 & 0.6 & 0.6 & 0.8 & 502 & 21 & 23 \\
\hline CN0004 & Hardangervidda & 0.50 & 120 & 643 & 14.5 & 1.7 & 1.6 & 2.0 & 1679 & 82 & 20 \\
\hline CN0005 & Hardangervidda & 0.50 & 120 & 643 & 14.5 & 1.7 & 1.6 & 2.0 & 1679 & 82 & 20 \\
\hline CN0006 & Hardangervidda & 0.50 & 120 & 643 & 14.5 & 1.7 & 1.6 & 2.0 & 1679 & 82 & 20 \\
\hline CN0007 & Hardangervidda & 0.50 & 120 & 643 & 14.5 & 1.7 & 1.6 & 2.0 & 1679 & 82 & 20 \\
\hline CN0008 & Hardangervidda & 0.50 & 120 & 643 & 14.5 & 1.7 & 1.6 & 2.0 & 1679 & 82 & 20 \\
\hline CN0009 & Hardangervidda & 0.50 & 120 & 643 & 14.5 & 1.7 & 1.6 & 2.0 & 1679 & 82 & 20 \\
\hline CN0010 & Hardangervidda & 0.50 & 120 & 643 & 14.5 & 1.7 & 1.6 & 2.0 & 1679 & 82 & 20 \\
\hline CN0011 & Hardangervidda & 0.50 & 120 & 643 & 14.5 & 1.7 & 1.6 & 2.0 & 1679 & 82 & 20 \\
\hline CN0012 & Hardangervidda & 0.50 & 120 & 643 & 14.5 & 1.7 & 1.6 & 2.0 & 1679 & 82 & 20 \\
\hline CN0013 & Hardangervidda & 0.50 & 120 & 643 & 14.5 & 1.7 & 1.6 & 2.0 & 1679 & 82 & 20 \\
\hline CN0014 & Hardangervidda & 0.50 & 120 & 643 & 14.5 & 1.7 & 1.6 & 2.0 & 1679 & 82 & 20 \\
\hline CN0015 & Hardangervidda & 0.50 & 120 & 643 & 14.5 & 1.7 & 1.6 & 2.0 & 1679 & 82 & 20 \\
\hline CN0016 & Kaarvatn & 0.35 & 91 & 764 & 5.9 & 5.3 & 8.0 & 1.8 & 2397 & 103 & 23 \\
\hline CN0017 & Kaarvatn & 0.35 & 91 & 764 & 5.9 & 5.3 & 8.0 & 1.8 & 2397 & 103 & 23 \\
\hline CN0018 & Rondane & 0.23 & 373 & 941 & 11.5 & 0.8 & 0.3 & 1.0 & N/A & N/A & N/A \\
\hline CN0019 & Rondane & 0.23 & 373 & 941 & 11.5 & 0.8 & 0.3 & 1.0 & N/A & N/A & N/A \\
\hline CN0020 & N/A & N/A & N/A & N/A & N/A & N/A & N/A & N/A & N/A & N/A & N/A \\
\hline CN0021 & N/A & N/A & N/A & N/A & N/A & N/A & N/A & N/A & N/A & N/A & N/A \\
\hline CN0022 & N/A & N/A & N/A & N/A & N/A & N/A & N/A & N/A & N/A & N/A & N/A \\
\hline
\end{tabular}

\section{APPENDIX 2}

Southern Norway dataset. Site, lake chemistry and soil data. Relative area: lake area/catchment area. Q= runoff.

\begin{tabular}{|c|c|c|c|c|c|c|c|}
\hline ID & Name & NIVA-Id & Latitude & Longitude & $\begin{array}{c}\text { Elevation } \\
\text { (m a.s.1.) }\end{array}$ & $\begin{array}{c}\text { RelArea } \\
(\%)\end{array}$ & $\begin{array}{c}\mathrm{Q} \\
\left(\mathrm{m} \mathrm{yr}^{-1}\right)\end{array}$ \\
\hline SN0002 & St. Eitlndsvt & $1004-13$ & 59.6350 & 8.1100 & 1053 & 0.4 & 0.789 \\
\hline SN0011 & Stigebottsvt & $1026-210$ & 58.7560 & 7.3150 & 814 & 4.4 & 1.577 \\
\hline SN0013 & Troldevatn & $1032-14$ & 58.2260 & 6.9930 & 278 & 4.0 & 0.946 \\
\hline SN0015 & Trollselvvtn & $1034-8$ & 58.5470 & 7.2060 & 617 & 2.4 & 1.419 \\
\hline SN0017 & Heievatn & $1037-17$ & 58.6300 & 6.9700 & 500 & 3.8 & 1.892 \\
\hline SN0019 & Skreppevatn & $1046-111$ & 58.9280 & 7.0460 & 812 & 2.5 & 1.735 \\
\hline SN0023 & Måkevatn & $1111-23$ & 58.3120 & 6.3800 & 272 & 4.0 & 1.577 \\
\hline SN0024 & Ljosvatn & $1111-3$ & 58.4180 & 6.2110 & 150 & 4.0 & 1.577 \\
\hline SN0025 & Gjuvvatn & $1112-15$ & 58.5220 & 6.4090 & 389 & 4.0 & 2.208 \\
\hline SN0028 & Homsevatn & $1119-602$ & 58.5620 & 5.8610 & 142 & 6.7 & 1.419 \\
\hline SN0029 & Kråtjørni & $1122-1-9$ & 58.7410 & 6.1210 & 534 & 0.7 & 2.208 \\
\hline SN0030 & Tvaravatnet & $1129-1-13$ & 59.0410 & 6.3100 & 720 & 4.0 & 1.892 \\
\hline SN0036 & Heddersvatn & $827-601$ & 59.8300 & 8.7560 & 1136 & 1.7 & 0.789 \\
\hline SN0041 & Folurdkaldevatn & $833-2-21$ & 59.3840 & 7.5930 & 1074 & 4.0 & 0.789 \\
\hline SN0042 & Skurevatn & $833-603$ & 59.5870 & 7.5530 & 1269 & 6.5 & 0.789 \\
\hline SN0043 & Hemletjørnane & $834-1-12$ & 59.6110 & 7.5440 & 1104 & 16.0 & 0.789 \\
\hline SN0044 & НOH 1394 & $834-1-32$ & 59.9380 & 7.9640 & 1394 & 1.8 & 0.789 \\
\hline SN0045 & Stavsvatn & $834-614$ & 58.4930 & 6.7350 & 392 & 1.3 & 1.577 \\
\hline SN0054 & Storolavsvatnet & $938-3-4$ & 58.8580 & 7.2860 & 848 & 12.2 & 1.577 \\
\hline SN0056 & HOH 1227 & $940-2-9$ & 59.1850 & 7.1080 & 1227 & 4.0 & 1.892 \\
\hline SN0059 & Skammevatn & $940-527$ & 59.2050 & 7.2420 & 1074 & 0.6 & 1.892 \\
\hline SN0060 & Reinsgrovtjørnane & $941-2-23$ & 59.3410 & 7.0060 & 1121 & 4.0 & 1.892 \\
\hline SN0061 & Bånevatn & $941-24$ & 59.5040 & 7.1130 & 1115 & 8.9 & 0.789 \\
\hline
\end{tabular}


Lake chemistry. Alk= alkalinity titrated to fixed $\mathrm{pH} 4.5$ less $32 \mu \mathrm{eq} \mathrm{1}^{-1}$.

\begin{tabular}{|c|c|c|c|c|c|c|c|c|c|c|c|c|c|c|}
\hline ID & Year & $\mathrm{pH}$ & $\begin{array}{c}\mathrm{Ca} \\
\left(\mu \mathrm{eq} 1^{-1}\right)\end{array}$ & $\frac{\mathrm{Mg}}{\left(\mu \text { eq } \mathrm{l}^{-1}\right)}$ & $\begin{array}{c}\mathrm{Na} \\
\left(\mu \text { eq } 1^{-1}\right)\end{array}$ & $\underset{\left(\mu \mathrm{eq} 1^{-1}\right)}{\mathrm{K}}$ & $\begin{array}{c}\mathrm{Cl} \\
\left(\mu \mathrm{eq} \mathrm{l}^{-1}\right)\end{array}$ & $\begin{array}{c}\mathrm{SO}_{4} \\
\left(\mu \mathrm{eq} 1^{-1}\right)\end{array}$ & $\begin{array}{c}\mathrm{NO}_{3} \\
\left(\mu \text { eq } 1^{-1}\right)\end{array}$ & $\begin{array}{c}\text { Alk } \\
\left(\mu \text { eq } 1^{-1}\right)\end{array}$ & $\begin{array}{c}\text { TOC } \\
\left(\mathrm{mg} \mathrm{l}^{-1}\right)\end{array}$ & $\begin{array}{c}\mathrm{R}-\mathrm{Al} \\
\left(\mu \mathrm{g} \mathrm{l}^{-1}\right)\end{array}$ & $\begin{array}{l}\text { org-Al } \\
\left(\mu \mathrm{g} \mathrm{l}^{-1}\right)\end{array}$ & $\begin{array}{l}\text { inorg-Al } \\
\left(\mu \mathrm{g} \mathrm{l}^{-1}\right)\end{array}$ \\
\hline SN0002 & 1995 & 4.89 & 22 & 31 & 125 & 4 & 147 & 57 & 15 & 0 & 0.5 & 137 & 7 & 130 \\
\hline SN0011 & 1995 & 4.90 & 14 & 10 & 39 & 5 & 42 & 28 & 6 & 0 & 2.3 & 88 & 32 & 56 \\
\hline SN0013 & 1995 & 4.55 & 17 & 30 & 133 & 4 & 147 & 59 & 25 & 0 & 1.0 & 180 & 15 & 165 \\
\hline SN0015 & 1995 & 4.58 & 17 & 18 & 59 & 2 & 60 & 38 & 5 & 0 & 8.1 & 125 & 93 & 32 \\
\hline SN0017 & 1995 & 4.65 & 19 & 18 & 68 & 3 & 71 & 42 & 5 & 0 & 5.6 & 150 & 115 & 35 \\
\hline SN0019 & 1995 & 5.10 & 12 & 9 & 34 & 2 & 38 & 25 & 8 & 0 & 1.1 & 88 & 17 & 71 \\
\hline SN0023 & 1995 & 4.73 & 26 & 52 & 197 & 5 & 245 & 76 & 28 & 0 & 0.7 & 322 & 27 & 295 \\
\hline SN0024 & 1995 & 4.75 & 26 & 47 & 194 & 5 & 236 & 71 & 26 & 0 & 0.5 & 268 & 30 & 238 \\
\hline SN0025 & 1995 & 4.83 & 17 & 32 & 127 & 4 & 150 & 55 & 16 & 0 & 0.6 & 189 & 15 & 174 \\
\hline SN0028 & 1995 & 4.81 & 31 & 53 & 207 & 6 & 248 & 74 & 25 & 0 & 0.8 & 231 & 11 & 220 \\
\hline SN0029 & 1995 & 4.82 & 17 & 30 & 124 & 3 & 148 & 44 & 8 & 0 & 2.1 & 120 & 59 & 61 \\
\hline SN0030 & 1995 & 5.02 & 11 & 21 & 89 & 4 & 103 & 31 & 10 & 0 & 0.8 & 88 & 17 & 71 \\
\hline SN0036 & 1995 & 5.85 & 31 & 9 & 15 & 4 & 16 & 30 & 9 & 8 & 0.7 & 18 & 11 & 7 \\
\hline SN0041 & 1995 & 5.64 & 18 & 7 & 18 & 4 & 18 & 25 & 6 & 3 & 0.1 & 41 & 5 & 36 \\
\hline SN0042 & 1995 & 5.44 & 16 & 8 & 19 & 1 & 27 & 21 & 10 & 0 & 0.2 & 58 & 5 & 53 \\
\hline SN0043 & 1995 & 5.64 & 18 & 8 & 19 & 1 & 19 & 24 & 8 & 2 & 0.4 & 50 & 5 & 45 \\
\hline SN0044 & 1995 & 5.48 & 17 & 7 & 11 & 3 & 8 & 25 & 11 & 1 & 0.4 & 25 & 5 & 20 \\
\hline SN0045 & 1995 & 5.93 & 41 & 9 & 20 & 4 & 16 & 33 & 4 & 16 & 1.0 & 65 & 22 & 43 \\
\hline SN0054 & 1995 & 5.08 & 12 & 10 & 40 & 2 & 45 & 27 & 11 & 0 & 0.8 & 98 & 11 & 87 \\
\hline SN0056 & 1995 & 5.32 & 10 & 6 & 16 & 1 & 17 & 19 & 7 & 1 & 0.2 & 34 & 5 & 29 \\
\hline SN0059 & 1995 & 5.56 & 14 & 6 & 22 & 2 & 23 & 19 & 6 & 3 & 0.4 & 41 & 5 & 36 \\
\hline SN0060 & 1995 & 5.22 & 8 & 8 & 22 & 2 & 25 & 17 & 6 & 0 & 0.3 & 25 & 5 & 20 \\
\hline SN0061 & 1995 & 5.33 & 11 & 7 & 26 & 2 & 31 & 17 & 8 & 0 & 0.2 & 40 & 5 & 35 \\
\hline
\end{tabular}

Soil chemistry. Depth=estimated average for catchment. $\mathrm{CEC}=$ cation exchange capacity by $1 \mathrm{M} \mathrm{NH}_{4} \mathrm{NO}_{3}$. BD=bulk density. Exchangeable base cations in $\%$ of CEC. N/A= not available.

\begin{tabular}{|c|c|c|c|c|c|c|c|c|c|c|}
\hline ID & $\begin{array}{l}\text { Depth } \\
(\mathrm{m})\end{array}$ & $\begin{array}{c}\text { CEC } \\
\left(\mathrm{meq} \mathrm{kg}^{-1}\right)\end{array}$ & $\begin{array}{c}\mathrm{BD} \\
\left(\mathrm{kg} \mathrm{m}^{-3}\right)\end{array}$ & $\begin{array}{c}\mathrm{Ca} \\
(\%)\end{array}$ & $\begin{array}{l}\mathrm{Mg} \\
(\%)\end{array}$ & $\begin{array}{l}\mathrm{Na} \\
(\%)\end{array}$ & $\begin{array}{c}\mathrm{K} \\
(\%)\end{array}$ & $\begin{array}{c}\mathrm{C} \\
\left(\mathrm{mmol} \mathrm{m}^{-2}\right)\end{array}$ & $\begin{array}{c}\mathrm{N} \\
\left(\mathrm{mmol} \mathrm{m}^{-2}\right)\end{array}$ & $\begin{array}{c}\mathrm{C} / \mathrm{N} \\
\left(\mathrm{mol} \mathrm{mol}^{-1}\right)\end{array}$ \\
\hline SN0002 & 0.38 & 44 & 689 & 5.2 & 3.1 & 4.1 & 4.3 & 2073 & 124 & 17 \\
\hline SN0011 & 0.14 & 72 & 552 & 13.9 & 7.3 & 2.6 & 5.0 & 770 & 53 & 15 \\
\hline SN0013 & 0.33 & 112 & 553 & 13.2 & 8.7 & 4.7 & 3.1 & 752 & 39 & 19 \\
\hline SN0015 & 0.12 & 39 & 558 & 9.6 & 5.8 & 2.2 & 4.5 & 489 & 33 & 15 \\
\hline SN0017 & 0.50 & 189 & 192 & 8.7 & 8.7 & 4.5 & 3.6 & 4674 & 141 & 33 \\
\hline SN0019 & 0.89 & 12 & 855 & 7.3 & 5.1 & 2.9 & 2.2 & 4944 & 137 & 36 \\
\hline SN0023 & 0.56 & 58 & 499 & 7.2 & 4.1 & 3.5 & 2.2 & 3140 & 178 & 18 \\
\hline SN0024 & 0.28 & 69 & 907 & 11.6 & 6.6 & 2.8 & 3.3 & 2073 & 124 & 17 \\
\hline SN0025 & 0.28 & 69 & 907 & 11.6 & 6.6 & 2.8 & 3.3 & 2910 & 151 & 19 \\
\hline SN0028 & 0.75 & 201 & 374 & 33.9 & 13.3 & 5.3 & 2.0 & 7114 & 351 & 20 \\
\hline SN0029 & 0.40 & 102 & 617 & 17.1 & 11.4 & 3.2 & 4.0 & 4112 & 184 & 22 \\
\hline SN0030 & 0.22 & 232 & 378 & 14.5 & 12.5 & 2.3 & 4.2 & 1793 & 58 & 31 \\
\hline SN0036 & 0.22 & 65 & 668 & 14.9 & 4.1 & 3.9 & 2.8 & 1019 & 33 & 31 \\
\hline SN0041 & 0.16 & 65 & 553 & 10.2 & 3.5 & 2.4 & 2.9 & 1042 & 34 & 30 \\
\hline SN0042 & 0.22 & 65 & 668 & 14.9 & 4.1 & 3.9 & 2.8 & 1019 & 33 & 31 \\
\hline SN0043 & 0.22 & 65 & 668 & 14.9 & 4.1 & 3.9 & 2.8 & 1019 & 33 & 31 \\
\hline SN0044 & 0.22 & 65 & 668 & 14.9 & 4.1 & 3.9 & 2.8 & 1019 & 33 & 31 \\
\hline SN0045 & 0.22 & 65 & 668 & 14.9 & 4.1 & 3.9 & 2.8 & 1019 & 33 & 31 \\
\hline SN0054 & 0.53 & 36 & 877 & 39.5 & 6.7 & 2.4 & 2.7 & 770 & 53 & 15 \\
\hline SN0056 & 0.22 & 232 & 378 & 14.5 & 12.5 & 2.3 & 4.2 & 1793 & 58 & 31 \\
\hline SN0059 & 0.22 & 232 & 378 & 14.5 & 12.5 & 2.3 & 4.2 & 1793 & 58 & 31 \\
\hline SN0060 & 0.22 & 65 & 668 & 14.9 & 4.1 & 3.9 & 2.8 & 1793 & 58 & 31 \\
\hline SN0061 & 0.22 & 65 & 668 & 14.9 & 4.1 & 3.9 & 2.8 & 1019 & 33 & 31 \\
\hline
\end{tabular}

